\title{
Milk lipid and protein traffic in mammary epithelial cells: joint and independent pathways
}

\author{
Michèle OlLIVIER-BousQueT* \\ Unité de Biologie Cellulaire et Moléculaire, INRA, \\ 78352 Jouy-en-Josas Cedex, France
}

\begin{abstract}
In mammary epithelial cells, milk lipids and proteins are synthesised in the same compartment, the endoplasmic reticulum. Lipids, carried through the cytoplasm, associate with the apical membrane which then pinches off and releases the lipid globule. Proteins, carried through membrane compartments are released in the lumen after fusion of secretory vesicles with the apical membrane. These processes assure a relatively constant composition of milk but it is not known whether lipid and protein secretion are linked. The protein composition of the milk fat globule membrane and the stimulatory effects of prolactin and oxytocin on lipid and protein secretion suggest that these processes are coupled and co-regulated. However, it is possible to observe a dissociation between the formation and the secretion of the two constituents, during differentiation and in various experimental conditions, and this suggests that coupling is not strictly required.
\end{abstract}

milk lipids / mammary epithelial cells / secretion

Résumé - Transport des lipides et des protéines du lait dans les cellules épithéliales mammaires. Dans la cellule épithéliale mammaire, les lipides et les protéines du lait sont synthétisés dans le même compartiment, le reticulum endoplasmique. Les lipides transportés à travers le cytoplasme s'accolent à la membrane plasmique apicale qui les enveloppe avant leur sécrétion. Les protéines, transportées dans des compartiments membranaires jusqu'aux vésicules de sécrétion, sont libérées dans la lumière après fusion des vésicules avec la membrane apicale. Ces processus assurent une composition relativement constante du lait. Cependant, on ne sait pas si ces deux types de sécrétion sont liés. La composition protéique de la membrane du globule gras et l'effet stimulant de la prolactine et de l'ocytocine sur la sécrétion des deux constituants suggèrent que synthèse et sécrétion sont liées et co-régulées. Cependant, la possibilité d'observer une dissociation entre la formation et la sécrétion des deux constituants suggère que ce couplage n'est pas obligatoire.

lipides du lait / cellule épithéliale mammaire / sécrétion

\footnotetext{
* Correspondence and reprints

E-mail: ollivier@jouy.inra.fr
} 


\section{INTRODUCTION}

Unresolved questions continue to intrigue mammary cell biologists, dairy scientists and technologists: Are the intracellular secretion processes of lipids and proteins (the two main components of milk) linked, and are they controlled by the same mechanisms.

Milk composition has been the subject of numerous studies, and in fact it is more appropriate to speak of the composition of "milks" in the plural to reflect the great variety of milks found in different mammals [26]. For example, average fat and casein concentrations are $183 \mathrm{~g} \cdot \mathrm{L}^{-1}$ and $104 \mathrm{~g} \cdot \mathrm{L}^{-1}$ in the rabbit, $38 \mathrm{~g} \cdot \mathrm{L}^{-1}$ and $4 \mathrm{~g} \cdot \mathrm{L}^{-1}$ in humans and $19 \mathrm{~g} \cdot \mathrm{L}^{-1}$ and $13 \mathrm{~g} \cdot \mathrm{L}^{-1}$ in the horse, respectively [16]. Milk composition also varies according to time since birth (colostrum versus mature milk). Breed, number of lactations, diet and season also cause variations in milk composition $[1,44$, 45]. However, these variations are adapted to the physiological status of the offspring and, as long as the mammary gland is healthy, they are strictly regulated. During established lactation, the concentration of caseins gradually increases and, in most species, milk fat concentration increases in parallel [16]. In the rat, fat concentration declines in early lactation, but after the first five days following birth, once lactation is established, both fat and protein concentrations remain constant [45].

One approach to the questions of interactions between the secretion of milk lipids and of proteins has been to describe the morphological aspects of each type of product secretion (Fig. 1). In mammary epithelial cells (MEC), lipid droplets are surrounded by a layer that is largely composed of proteins and polar lipids. Caseins, in filamentous form or aggregated in micelles, are contained in secretory vesicles. Sometimes, lipid droplets are completely surrounded by secretory vesicles. Based on this observation, it has been proposed that there is inter- action between the secretory vesicle and the lipid droplet [69]. But this mechanism might be limited to periods when milk secretion is inhibited (discussed in [27]). Lipid globules in milk differ from intracellular lipid droplets in that they have a membrane, the milk fat globule membrane (MFGM), which is derived from apical membrane. Casein micelles have the same honeycomb appearance in milk as in secretory vesicles.

Another approach to the question of interactions between secretion of lipids and proteins has been to study their secretory pathways. The cellular mechanisms for milk component transport by the MEC have been recently reviewed $[7,27,64]$. Three main intracellular pathways have been described:

(1) A pathway ending with exocytosis: This pathway involves the transport of newly synthesised proteins from the endoplasmic reticulum (ER) to the Golgi apparatus and through the trans Golgi network (TGN) to the secretory vesicles. Secretory vesicles containing mature caseins, whey proteins, lactose, citrate and soluble salts, release their contents into the lumen of the acinus by exocytosis $[7,38]$. In addition, a small quantity of newly synthesised proteins, including milk proteins, hormone receptors and enzymes, is carried to the basolateral membrane [17].

(2) An endocytotic and transcytotic pathway involving internalisation of plasmaborne components into the cell and their transport into the milk [50]: during transport, a sorting of internalised molecules strictly controls the destination of the transcytosed products [41, 61].

(3) Milk lipid droplets are carried from the ER where they are synthesised to the apical region; they then bud from the apical membrane and are released into the lumen enveloped in the MFGM [27].

Despite all this information, it is not yet possible to describe how the MEC coordinates the synthesis and secretion of milk components to produce milk with a constant composition. 

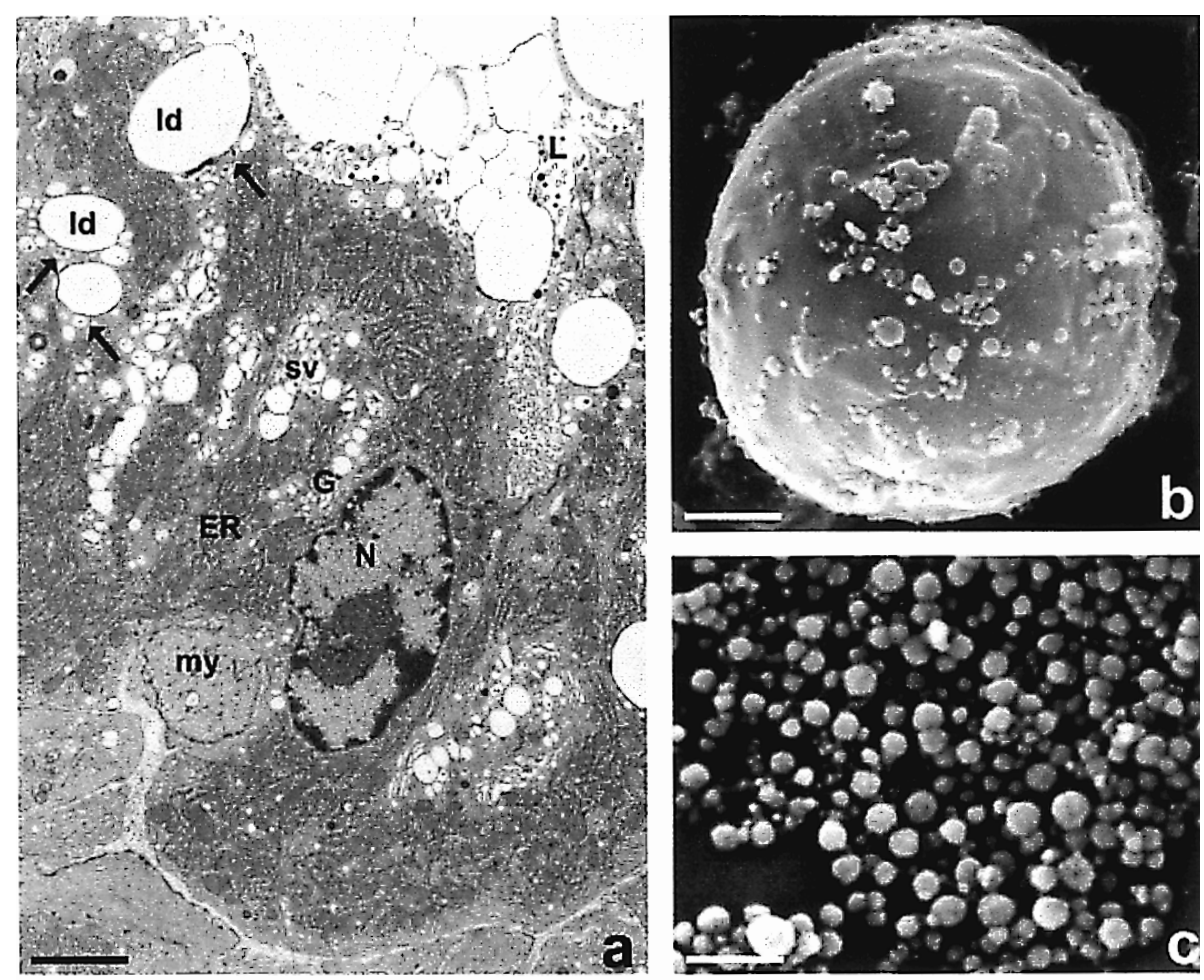

Figure 1. Morphological aspects of lactating mammary epithelial cells, milk lipid globule and casein micelles. (a) Lactating rabbit mammary epithelial cell contains well developed endoplasmic reticulum (ER), Golgi apparatus (G), secretory vesicles containing casein micelles (sv), and lipid droplets (ld). Some secretory vesicles are associated with lipid droplets (arrows). In the lumen (L), lipid globules and casein micelles are detectable. N: nucleus; my: myoepithelial cells. Bar $2 \mu \mathrm{m}$. (b) Scanning electron micrograph of sheep milk lipid globule. Bar $0.5 \mu \mathrm{m}$. (c) Scanning electron micrograph of sheep milk casein micelles. Bar $0.5 \mu \mathrm{m}$.

The important role of one gene, which codes for a key enzyme in lipid synthesis, has recently been reported [65]: inactivation of the gene for acyl-CoA: diacylglycerol acyltransferase (DGAT), an enzyme that catalizes the final esterification reaction in the biosynthesis of triacylglycerol (TAG), results in mice which do not lactate. Whereas these DGAT-null mice have normal serum lipid levels, no TAG synthesis is detectable in mammary tissue during lactogenesis. These results suggest that expression of one gene coding for a key enzyme in lipid synthesis is necessary for lactogenesis and subsequent milk secretion.
Control of synthesis of milk lipids and proteins may occur at the transcriptional level and involve control of gene activation. There remains the question of whether or not the genes involved in milk lipid and milk protein synthesis are activated simultaneously during final differentiation of the MEC. The expression of genes coding for proteins involved in the synthesis of proteins in the ER may have repercussions on the synthesis of lipids in that organelle. On the other hand, metabolic control of the exocytosis of secretory vesicles may be responsible for replenishing the apical membrane by secretory vesicle membranes and 
consequently be favourable to the release of lipid globules enveloped in the MFGM.

In this review, after a brief description of the formation of milk lipid globules, we will compare the expression of milk lipids and proteins during differentiation of MEC and the regulation of their intracellular transport.

\section{FORMATION OF MILK LIPID GLOBULES}

Recent reviews have given exhaustive historical accounts of research on milk fat globules, their surrounding membranes, and their origin, growth and secretion [27, 39]. In brief, the first to observe fat globules of microscopic dimensions in milk was van Leeuwenhoeck in 1674. The description of a membrane composed of phospholipids and proteins, stabilising the milk lipid globule, was confirmed by electron microscope observations, which showed the lipid droplet enveloped in the plasma membrane in the apical cell region [5]. The composition of MFGM was described in biochemical studies [56]. Since these pioneering studies, numerous data have made it possible to describe general aspects of how milk lipid globules are formed and secreted. The fatty acids that compose the TAG, are either supplied exogenously from plasma lipids or synthesised de novo via acetyl-CoA carboxylase and fatty acid synthetase [12]. Small lipid droplets, known as microlipid droplets, may originate from the ER where acyltransferases have been localised by cell fractionation. Microlipid droplets form in or on the ER and are released into the cytoplasm (reviewed in [39]). A protein identified as adipocyte differentiation-related protein (ADRP) was found in homogenates of lactating mammary gland, in ER and in lipid droplet fractions [23]. It was then suggested that this protein might be involved in the deposition of TAG in droplets as it occurs in adipocytes. For other cell types, the mechanisms of lipid droplet formation in the bilayer of the ER membrane and the processes of storage in the cytoplasm have been described [10, 42]. For example, in adipocytes and certain plant seeds, lipid droplets are believed to form by coalescence of neutral lipids into discs inside the bilayer of the ER membranes. The discs grow into spheres and may bud from the ER into the cytoplasm as droplets surrounded by a phospholipid monolayer derived from the ER [10]. In adipocytes and steroidogenic cells, ADRP is mainly expressed during differentiation and another protein, perilipin, is expressed during the lipid storage phase. It has been suggested that perilipin might sterically block access of the hormone-sensitive lipase, which catalyses the rate-limiting step in TAG hydrolysis, to the droplet surface $[9,33]$. It is not yet known whether there are similar mechanisms in MEC for regulating the growth or lipolysis of the lipid droplet. However, ADRP is always present in the MFGM after lipid globules have been secreted into milk [23], suggesting that the lipid droplet storage mechanisms here are not the same as those described in adipocytes.

Caveolins, a family of membrane-proteins, form the coatings of caveolae that are generally restricted to cell surface and Golgi apparatus. Caveolins contain NH2- and $\mathrm{COOH}$-terminal domains that project into the cytosol with a central domain in the lipid phase of the membrane. It has been shown that, when caveolin-1 and, to a lesser extent, caveolin-2 accumulate in the ER, they can be found in association with the membranes surrounding lipid droplets [54] and may play a part in maintaining cholesterol balance [59]. Moreover, the presence of caveolin-2 in a raft-like membrane domain on the lipid droplet surface may be involved in intracellular signalling [19]. These authors posit that caveolin plays a role in controlling lipid droplet transport and storage. Caveolin has been detected in lactating mouse MEC [55]. It will be interesting to localise caveolin in MEC under different physiological or experimental conditions, to see whether there is a 
similar interaction between caveolin and lipid droplet surfaces in MEC.

Many other ER membrane and luminal proteins have been identified in MFGMs and in lipid droplets [22, 70]. Some ER luminal proteins (calreticulin, protein disulfide isomerase, immunoglobulin-binding protein), are associated with intracellular lipid droplets but are not detectable in MFGM, suggesting that they are lost during secretion [22]. Taken together, these examples suggest that ER proteins may be involved in lipid droplet formation or transport. Interestingly, a reduced level of casein and lipid secretion has been described in goats with mutations of the $\alpha_{\mathrm{s} 1}$-casein gene ([43] in this issue and reference therein). In these animals, very low levels of $\alpha_{\mathrm{s} 1}$-caseins are synthesised and the transport of the other caseins through the ER is greatly delayed [11]. It is not known whether these abnormalities in the ER are responsible for the low milk lipid concentration found in these animals.

Cytosolic proteins known to be related to membrane trafficking have also been detected in lipid droplets and MFGM [70]. A cytoplasmic protein called TIP 47, which functions as a receptor for mannose 6-phosphate receptors by binding to the cytoplasmic domain of these receptors, has a structure homologous to that of ADRP (43\% identical). It has therefore been suggested that this protein might be involved in both membrane vesicle traffic and lipid droplet traffic [68]. Controversial results obtained in different cell types have been published [4]. However, using a specific antibody raised against a N-terminal peptide sequence of TIP 47, Heid and Keenan (unpublished results) showed that TIP 47 was associated with MFGM. A cytoplasmic protein interacting both with the lipid droplet surface and with secretory vesicles might explain the association of fat droplets and secretory vesicles described above.

The mechanisms of lipid droplet growth and translocation within the cell remain hypothetical. Droplet diameters vary from $0.5 \mu \mathrm{m}$ or less to $8 \mu \mathrm{m}$ or more. Microlipid droplets may fuse with preformed cytoplasmic lipid droplets [18, 67]. Fusion between large droplets has not been observed. Incorporation of fatty acid precursors of TAG from rabbit and sheep MEC, monitored by electron microscope autoradiography, shows that fatty acids are incorporated in a few minutes in lipid droplets of large diameter and are very quickly released into the lumen [15]. Stemberger and Patton [66] have suggested that control of the growth process may occur after the droplet has made contact with the apical membrane. Altogether, these results support the hypothesis of continuous growth of droplets simultaneously with release into the alveolar lumen.

Lipid globules in the milk of at least some species vary considerably in size [28]. It is not known whether some smaller droplets have been secreted or whether larger droplets have broken up during or after secretion. However, each mammalian species tends to accumulate milk lipids in droplets of a relatively narrow size range, suggesting that size is regulated.

The fusion of droplets with the apical membrane is a key mechanism in the process of milk lipid secretion. In cytoplasm, lipid droplets are associated with ADRP. In milk, lipid globules contain abundant proteins associated with the MFGM, including butyrophilin and xanthine oxidase [39]. Butyrophilin, a membrane glycoprotein, accumulates close to the apical membrane of the MEC [3]. It has been suggested that xanthine oxidase, a soluble protein, binds to the cytoplasmic domain of butyrophilin associated with the plasma membrane, and that this scaffold may act as a receptor for binding the cytosolic droplet through interaction with ADRP until the lipid droplet is completely enveloped in the apical membrane, which then pinches off and releases the milk lipid globule [39]. There is presumed to be coordination between the two 
secretion processes - that of the aqueous phase constituents of milk (lactose, water, ions, whey proteins and caseins), by exocytosis after the secretory vesicles have fused with the plasma membrane, and that of the fat globules, by envelopment in the apical plasma membrane. Among the protein markers of the apical membrane, MUC1, a glycoprotein of the mucin family, is present in large amounts in MFGM $[35,36]$. Immunoelectron microscopy localisation of MUC1 in lactating guinea pig MEC shows that this mucin is concentrated on the apical surface of the mammary epithelial cells and on secreted fat globules. By contrast, secretory vesicle membranes show relatively low concentrations of MUC1 [37]. These observations suggest that secretory vesicle membrane does not directly give rise to the apical membrane from which MFGM is derived. To know whether proteins are redistributed after fusion of the secretory vesicles and apical plasma membrane, the protein composition of these membranes will have to be described.

\section{FORMATION OF LIPID DROPLETS IN MAMMARY EPITHELIAL CELLS AT VARIOUS STAGES OF DIFFERENTIATION}

\subsection{Differentiation during pregnancy}

The timing and sequence of specific differentiation events differ according to species and breed [34, 71]. In vivo, it seems that MEC are able to express casein mRNAs as soon as they become organised in buds. In the rabbit mammary gland, the level of mRNAs coding for $\alpha_{\mathrm{s} 1}$-casein, $\beta$-casein, $\kappa$-casein and WAP increases as pregnancy proceeds and is relatively high during late pregnancy $[25,60]$. Milk products are synthesised in MEC at the end of pregnancy, although milk synthesis remains moderate. However, the time at which morphologically detectable secretory products appear in the cytoplasm of the MEC varies from species to species [58]. The changes observed in rabbit mammary gland during pseudopregnancy and pregnancy illustrate well the sequence in which milk products appear in the MEC. The morphological appearance of the MECs shows that in early pregnancy (9th day), the cytoplasm contains a few small lipid droplets. The Golgi apparatus is reduced to small stacks and no secretory vesicles or casein micelles are detectable. The lumen of the acini contains granular and filamentous products. At days 14-19 of pregnancy or at 12-14 day of pseudopregnancy, the cytoplasm has a similar appearance but the lipid droplets are larger and more abundant and the lumen is filled with an homogenous electron-dense product [8]. In MEC from some rabbits, at this stage, a few casein micelles are detectable in the cytoplasm. However, instead of being localised in secretory vesicles filled with a lucent content as observed during lactation, they are surrounded by a closely apposed membrane. The Golgi apparatus is composed of a small number of stacked saccules. These observations show that during the early stages of pregnancy, although milk protein mRNAs are present, caseins are not detectable in micellar form. Secondly, it appears that lipid droplets are present earlier in pregnancy than casein micelles. It is worth noting that, at the end of pregnancy when the secretory processes are not yet well established, very large lipid droplets accumulate inside the cell and are also found in the lumen of the acini.

\subsection{In vitro differentiation}

HC11 cells, a clonal derivative of the COMMA-1D cell line, have been used as a model for studying hormonal regulation of mammary cell differentiation [2]. Prolactin (PRL) and cortisol regulate the expression of $\beta$-casein and of xanthine oxidoreductase, a constituent of the milk lipid globule [40]. Epidermal growth factor blocks the stimulation of $\beta$-casein by PRL and cortisol, but 
in the presence of these hormones it increases the expression of xanthine oxidoreductase. Lactogenic hormones stimulate xanthine oxidoreductase by a signalling pathway involving the MAP kinase pathway, whereas the JAK/Stat pathway is the main pathway involved in the activation of $\beta$-casein expression [40].

Mammary epithelial cells from a 12-day pseudo-pregnant rabbit, cultured in two chambered cell culture plates, became polarised. After 12 days of culture in the presence of PRL, insulin and glucocorticoids, numerous large lipid droplets were present in the cytoplasm and the apical region of the cells, partly surrounded by the apical membrane (Fig. 2). No casein micelles were detectable in these cells. Thus, in vitro under hormonal control, milk lipid synthesis and milk lipid droplet formation occur before casein micelle formation, just as in vivo during pregnancy. It may be that lipid droplets and casein micelles are formed independently. The lipid droplets reach very large diameters in these conditions, suggesting that they continue to grow and are not efficiently secreted.

\subsection{Inhibition of protein synthesis and transport in fully differentiated and actively secreting MEC}

One way to study whether milk protein and lipid secretion are associated is to inhibit synthesis or transport of one and measure any effect this has on the secretion of the other. Unfortunately, to our knowledge, no data on this are available in the literature so far. Inhibition of protein synthesis by cycloheximide added in vitro to mammary
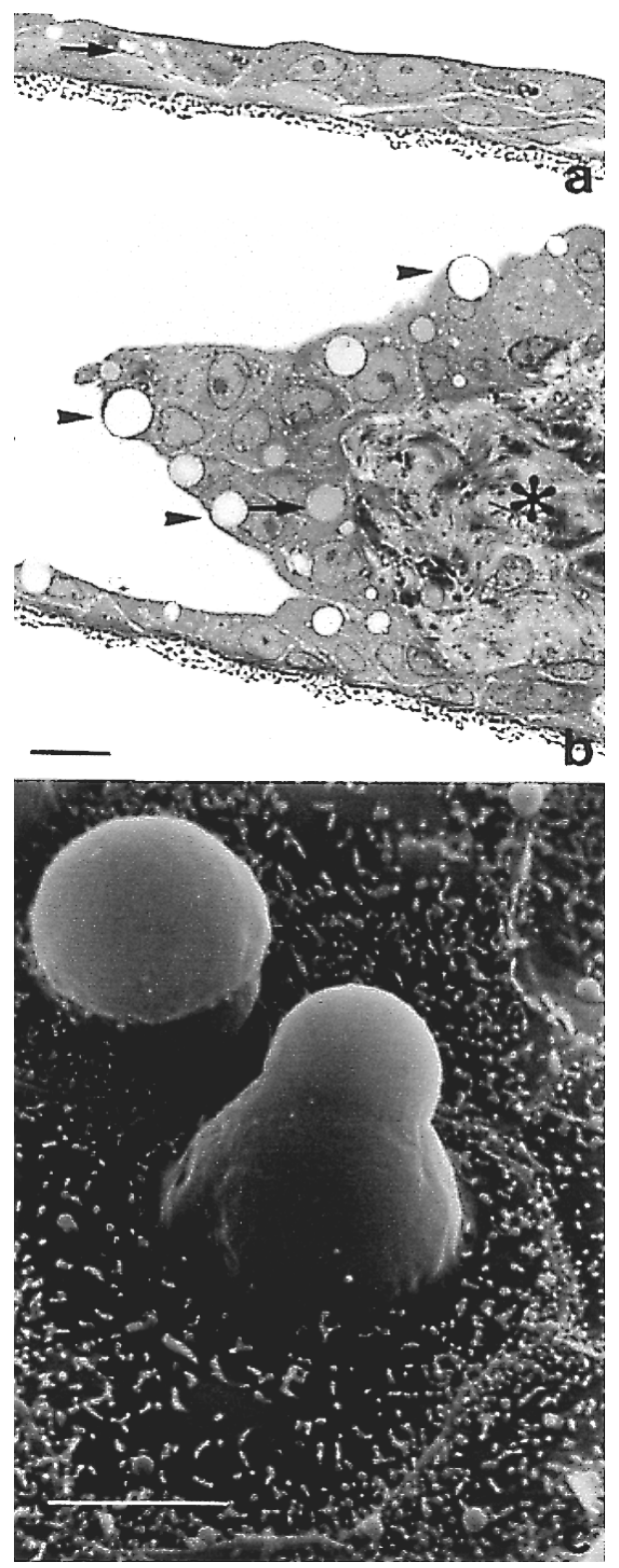

Figure 2. Mammary epithelial cells from a 12 day pseudo-pregnant rabbit cultured on two chambered cell culture plates. (a) Cells were cultured for three days in the presence of insulin plus cortisol. A few smaller lipid droplets were detectable in the cytoplasm (arrow). (b) Cells were cultured for three days in the presence of insulin plus prolactin plus cortisol. Large lipid droplets are present in the cytoplasm (arrow). Numerous lipid droplets bind at the apical membrane (arrowheads). No casein micelles are detectable. In some regions of the sheet, cells are surrounding a matrix-like formation (asterisk). Bar $10 \mu \mathrm{m}$. (c) Scanning electron micrograph of protruding lipid droplets on the apical side of the cells. Bar $5 \mu \mathrm{m}$. 
fragments induced an inhibition of 80-90\% of casein secretion in one hour. Morphological observations revealed that, in these conditions, very few secretory vesicles containing casein micelles remained detectable whereas numerous small, empty vesicles were present in the cytoplasm. It can be supposed that pre-existing secretory vesicles had released their contents during the onehour treatment. On the other hand, lipid droplets of various sizes were still present in the cytoplasm (Ollivier-Bousquet, unpublished results). This suggests either that lipid synthesis continues in the absence of protein synthesis or that previously synthesised lipids accumulate in the cytoplasm and are not released into the lumen when protein synthesis is inhibited.

Protein secretion is inhibited in MEC in vitro by adding brefeldin A (BFA), a drug that disorganises the Golgi region [57]. After 60 min' incubation in the presence of BFA, Golgi stacks and secretory vesicles have completely disappeared and the ER fills the cytoplasm. Lipid droplets of various sizes are present in the cytoplasm. Large lipid droplets are in close contact with the apical membrane. Numerous lipid globules are detectable in the lumen (Fig. 3). Thus, although the secretory vesicles have disappeared, lipid droplets are still present, as was observed after protein synthesis inhibition. To draw any conclusions as to the importance of the integrity of Golgi apparatus for lipid droplet transport, one would have to determine whether these lipids preexisted the action of the BFA or are newly synthesised.

\section{REGULATION OF INTRACELLULAR TRANSPORT AND SECRETION OF LIPID DROPLETS}

Between two nursings or milkings, milk constituents are released from their sites of synthesis in MEC into the lumen of the acini by continuous secretion. In addition, at each nursing or milking, pituitary hormones such as PRL and oxytocin are discharged. This regular peaking of PRL and oxytocin circulation is necessary to maintain the synthetic activities of the MEC and empty the acini.

The binding of PRL to its receptors has several biological effects, including the control of gene expression [24] and a metabolic effect, the secretagogue effect, which has
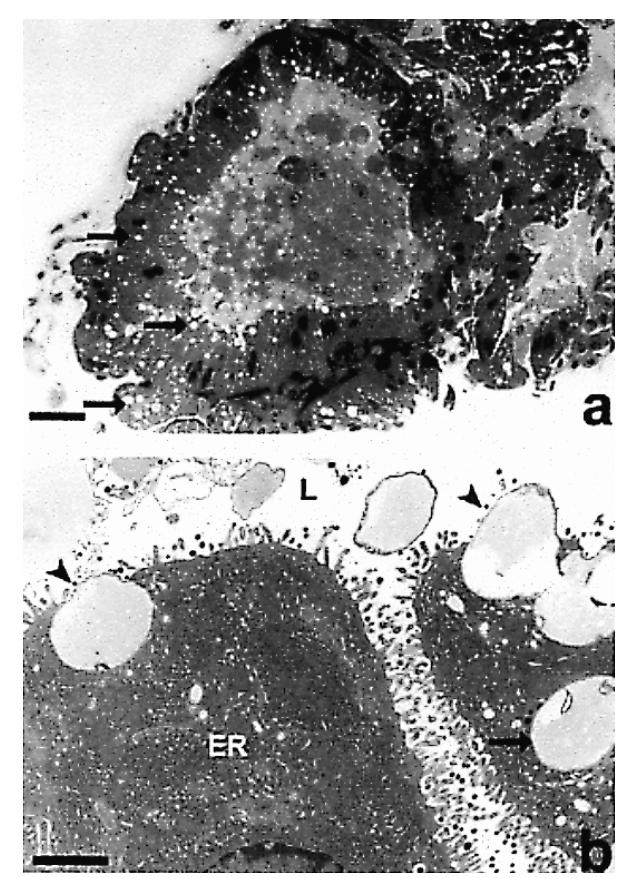

Figure 3. Morphological aspects of rabbit lactating mammary epithelial cells incubated in the presence of brefeldin A. (a) Section of an acinus after $5 \mathrm{~min}$ incubation in the presence of $5 \mu \mathrm{M}$ brefeldin A. The cytoplasm is filled with endoplasmic reticulum. Golgi apparatus and secretory vesicles are not detectable. Small size lipid droplets are present in the cytoplasm (arrow). Bar $10 \mu \mathrm{m}$. (b) Electron micrograph of rabbit lactating mammary epithelial cells after $60 \mathrm{~min}$ of incubation in the presence of $5 \mu \mathrm{m}$ brefeldin A. The cytoplasm is filled with endoplasmic reticulum (ER). Lipid droplets are present in the cytoplasm (arrow), in the apical region of cell (arrowheads) and in the lumen (L). Bar $1 \mu \mathrm{m}$. 
been described in vitro [51]. This secretagogue effect produces a very rapid increase of milk protein secretion [17, 29, 49]. PRL signalling for the secretagogue effect involves a rapid but transient release, and metabolism, of arachidonic acid [6]. Lipoxygenase metabolites of arachidonic acid may be involved in interactions and fusions between intracellular membranes. Consequently, lipid secretion, which depends on the lipid globule being enveloped by the apical membrane, may also be affected by the increased metabolism of arachidonic acid induced by PRL. In fact, in vitro, PRL stimulates lipid secretion in the same way as protein secretion [15]. Metabolic labelling of milk lipids in a 3-min pulse, followed by a 120 -min chase, revealed that $98 \%$ of the TAG in the intracellular lipids was radioactive compared to $71 \%$ of the TAG in the lipids secreted into the medium. PRL added after the pulse increased the radioactivity of TAG in lipids secreted into the medium. Morphological evaluation of the distribution of lipid globules between the cytoplasm and the lumen of the acinus showed that in the presence of PRL, more lipid globules are secreted into the lumen than into a control medium [52]. These results suggest that PRL stimulates the secretion of growing lipid droplets enriched with newly synthesised radioactive triglycerides, whereas, in MEC incubated in a control medium, growing lipid droplets accumulated in the cytoplasm for a longer period. Incorporation into these lipids of non radioactive, newly synthesised triglycerides may continue during the chase; this would explain the lower percentage of radioactivity in the triglycerides. This hypothesis is in accordance with the suggestion that growth, envelopment in the apical membrane and release of the lipid droplet occur simultaneously. If this is the case, PRL, by stimulating lipid secretion, might increase the release of smaller lipid globules. To verify this hypothesis, morphological studies to assess the diameters of released lipid globules will be required.
Oxytocin provokes a contraction of myoepithelial cells and ejection of milk from the mammary acini. Regular removal of milk from the mammary gland due to an increase in the number of milkings or to exogenous oxytocin administration, increases milk production ([31] in this issue and references therein). This increase is accompanied by qualitative changes in milk composition due to better alveolar milk transfer. Oxytocin stimulates release of TAG from rat mammary gland slices [14]. It has been suggested that oxytocin may directly act on intracellular transport of newly synthesised proteins in the MEC [48] by an effect on epithelial cells [32].

These results show that PRL, and possibly oxytocin, exert direct effects on the mammary epithelium, stimulating milk lipid secretion. The mechanisms of these hormones' action on lipid secretion are not known. Monomeric GTP-binding proteins are key regulator of vesicular transport in eukaryotic cells [63]. A class of low molecular mass GTP-binding proteins are tightly associated with the lipid droplet surface and with the MFGM. These GTP-binding proteins co-enrich with xanthine oxidase and butyrophilin during purification, suggesting that they may be associated with the coat structure located on the inner face of the MFGM. These GTP-binding proteins also play a role in the transduction of various signals. It has been postulated that they may also play role in transduction of the signal needed for regulating vectorial transport of lipid droplets. In agreement with this hypothesis, adding GTP $\gamma$ s to the incubation medium of permeabilised acini increases the release of newly synthesised lipids [21]. Identifying the factors that regulate the activity of GTP-binding proteins associated with lipid droplets and MFGM will provide an understanding of the role of these proteins.

A $\beta$ subunit of a trimeric $G$ protein has been found in MFGM but not in lipid droplets [70]. Trimeric $G$ proteins are classically known to be involved in the 
transduction of various signalling systems, and could play a regulatory role in the last stages of fusion at the apical plasma membrane.

Transport within MECs involves the elements of the cytoskeletal system. Actin and microtubules constitute a network that is related to the polarity of the epithelium [30]. Actin is located at the periphery of the cell, in close apposition to the basolateral and apical membrane. Microtubules are found in the apical and medial portions of cytoplasm, associated with vesicles [46]. Colchicine and other microtubule-altering drugs inhibit the secretion of milk components both in vivo and in vitro (references in [30]). Colchicine produces cytoplasmic disorganisation and loss of microtubules and causes intracellular accumulation of secretory vesicles followed by a decrease in protein, lactose and lipid secretion [47]. When measured in vitro, colchicine added to an incubation medium did not modify the secretion of radioactive triglycerides labelled in a 3-min pulse followed by a 120 -min chase, whereas secretion of newly synthesised proteins was completely inhibited in similar experimental conditions $[15,53]$. This suggests that at least during the timewindow studied, and with the concentrations of colchicine used in these experiments, intracellular transport of proteins requires the microtubule system, while that of lipids does not. In agreement with this, it is worth noting that no important association between microtubules and lipid droplets has been detected in morphological studies [46]. On the other hand, proteins such as dynein, motor protein, gelsolin and gephyrin, which are known to be associated with microtubules and actin and to be involved in the binding and movement of vesicular cargoes, have been found in isolated MFGMs and mammary lipid droplets [70]. It is not clear by what mechanism the cytoskeletal system might be involved in the regulation of lipid droplet transport.

\section{CONCLUSIONS AND PERSPECTIVES}

Lipid droplets and casein micelles in their mature forms do not appear simultaneously during pregnancy and during differentiation of MEC in vitro. During established lactation, secretion of the two constituents is parallelly regulated. However, it may be possible to dissociate protein secretion and lipid secretion in various experimental conditions. Answering questions as to possible interaction between these two types of secretion requires knowledge of the intracellular transport mechanisms involved.

The secretory pathways of milk constituents have been well described. The lactating MEC conveys newly synthesised milk proteins by a process involving considerable membrane flow, which is used now as a model of cisternal maturation trafficking $[13,20,38]$. Another type of endomembrane trafficking involves endocytosis of membrane-associated molecules, and a meeting of the endocytic and exocytic pathway has been described [50, 61, 62]. Such membrane traffic may be required at each stage of milk lipid droplet transport: formation in the ER, growth and transit, associated or not with secretory vesicles, and secretion after envelopment in the apical plasma membrane.

Milk components are secreted into the lumen of the acinus by a constitutive secretory pathway, which depends on the hormonal state of the animal. In addition, at each nursing or milking there is a peak in oxytocin and PRL release into the blood, giving transient high concentrations of these hormones. These high concentrations may be responsible in vivo for the secretagogue effect described in vitro.

The mechanisms involved in these processes have yet to be understood, to discover whether or not lipid and protein secretions are associated in the MEC.

Several questions be can raised and partly answered using molecular cell biological approaches. 
(1) How do nascent lipid droplets bud off from their site of synthesis in the ER? Recent findings show that a neutral lipid core surrounded by a phospholipid monolayer bulges as lipids accumulate in the centre of the ER membrane, excluding transmembrane proteins but containing proteins with long hydrophobic amino acid sequences [10]. In this way, newly synthesised proteins can enter the droplets. In mouse MEC, the expression of caveolin-1 is down-regulated during late pregnancy and lactation whereas caveolin-2 decreases only slightly [55]. Do caveolins associate with lipid droplets in the MEC? Since caveolin-1 and caveolin- 2 have the property of forming hetero-oligomers, do variations in the expression of caveolin-1, in relation to physiological stage, play a part in a regulatory function of caveolin-2? These questions can now be partly answered by combining proteomic analysis of the protein composition of MEC with immunocytochemical localisation of caveolins and other proteins associated with the lipid droplets.

(2) What determines the polarised transport of lipid droplets? As mentioned above, lipid droplet transport has been ascribed to association with secretory vesicles. However, lipid droplets are able to reach the apical region and be released into the lumen of the acini in MEC in which no secretory vesicles are detectable in the cytoplasm or around the lipid droplets. Thus, association with secretory vesicles does not seem strictly required for vectorial transport. Cytoskeletal components may play a role in vectorial movements of lipid droplets to the apical plasma membrane. Controversial results suggest that the mechanisms involving the cytoskeletal system are complex. Complementary investigations will be needed to describe more precisely the possible interactions between microtubules, actin and proteins in association with lipid droplets.

(3) What determines the mature size of the lipid globule and the release of the droplet into the lumen? It has long been known that a lipid droplet grows in size as it moves to the apical region of the cell [66] and it has been suggested that it continues to grow while protruding from the apical membrane. So the rate of release may determine the size of the lipid globules secreted. The secretagogue effect of PRL may increase the release of secretory vesicles and lipid globules. Oxytocin may also induce release of milk constituents. Do these hormones play a part in determining the size of the lipid globules secreted? What mechanisms are involved in determining envelopment, fusion and detachment of the MFGM? To answer these questions, comparative analysis of genes expressed in MEC during pregnancy and lactation will be informative. Cytoplasmic and membrane proteins mediate fusions between vesicles. A large number of these proteins are known [63]. With proteomic analysis of the protein composition of MEC it will be possible to describe the proteins involved in these fusion processes under different experimental conditions of hormonal stimulation. However, to interpret the complex interactions between the proteins active in these processes, knowledge of their spatial and temporal recruitment at specific locations will be needed. For this, precise detection of these molecules in their cellular environment will be necessary.

\section{ACKNOWLEDGEMENTS}

The author is grateful to Dr T.W. Keenan for critically reading the manuscript, to S. Delpal for his assistance in performing the electron microscopy analysis, to Drs J.-L. Servely and R. Malienou N'Gassa in performing cell cultures and to M.-E. Marmillod for preparing the manuscript.

\section{REFERENCES}

[1] Allen J.C., Keller R.P., Archer P., Neville M.C., Studies in human lactation: milk composition and daily secretion rates of macronutrients in the first year of lactation, Am. J. Clin. Nutr. 54 (1991) 69-80. 
[2] Ball R.K., Friis R.R., Schoenberger C.A., Doppler W., Groner B., Prolactin regulation of beta casein gene expression and of a cytosolic $120-\mathrm{kD}$ protein in a cloned mouse mammary epithelial cell line, EMBO J. 7 (1988) 2089-2095.

[3] Banghart L.R., Chamberlain C.W., Vellarde J., Korobko I.V., Ogg S.L., Jack L.J.W., Vakharia V.N., Mather I.H., Butyrophilin is expressed in mammary epithelial cells from a single-sized messenger RNA as a type I membrane glycoprotein, J. Biol. Chem. 237 (1998) 4171-4179.

[4] Barbero P., Buell E., Zulley S., Pfeffer S.R., TIP 47 is not a component of lipid droplets, J. Biol. Chem. 276 (2001) 24348-24351.

[5] Bargmann W., Knoop A., Uber die morphologie der milchsekretion. Light- und electronmikroscopische studie an der milchdrüse der ratte, Z. Zellforsch. Mikrosk. Anat. 49 (1959) 344-388.

[6] Blachier F., Lacroix M.C., Ahmed-Ali M., Léger C., Ollivier-Bousquet M., Arachidonic acid metabolism and casein secretion in lactating rabbit mammary epithelial cells: Effects of inhibitors of prostaglandins and leukotrienes synthesis, Prostaglandins 35 (1988) 259-276.

[7] Boisgard R., Chanat E., Lavialle F., Pauloin A., Ollivier-Bousquet M., Roads taken by milk proteins in mammary epithelial cells, Livest. Prod. Sci. 70 (2001) 49-61.

[8] Bousquet M., Fléchon J.E., Denamur R., Aspects ultrastructuraux de la glande mammaire de lapine pendant la lactogenèse, Z. Zellforsch. 96 (1969) 418-436.

[9] Brasaemle D.L., Rubin B., Harten I.A., Gruia-Gray J., Kimmel A.R., Londos C., Perilipin A increases triacylglycerol storage by decreasing the rate of triacylglycerol hydrolysis, J. Biol. Chem. 275 (2000) 38486-38493.

[10] Brown D.A., Lipid droplets: Proteins floating on a pool of fat, Curr. Biol. 11 (2001) R446-R449.

[11] Chanat E., Martin P., Ollivier-Bousquet M., $\alpha_{s 1}$-casein is required for the efficient transport of $\beta$ - and $\kappa$-casein from the endoplasmic reticulum to the Golgi apparatus of mammary epithelial cells, J. Cell Sci. 112 (1999) 3399-3412.

[12] Clegg R.A., Barber M.C., Pooley L., Ernens I., Larondelle Y., Travers M.T., Milk fat synthesis and secretion: molecular and cellular aspects, Livest. Prod. Sci. 70 (2001) 3-14.

[13] Clermont Y., Xia L., Rambourg A., Turner J.D., Hermo L., Transport of casein submicelles and formation of secretion granules in the Golgi apparatus of epithelial cells of the lactating mammary gland of rat, Anat. Rec. 235 (1993) 353-373.

[14] Da Costa T.H.M., Taylor K., Ilic V., Williamson D.H., Regulation of milk lipid secretion: effects of oxytocin, prolactin and ionomycin on triacylglycerol release from rat mammary gland slices, Biochem. J. 308 (1995) 975-985.
[15] Daudet F., Augeron C., Ollivier-Bousquet M., Effet rapide in vitro de la colchicine, du chlorure d'ammonium et de la prolactine sur la sécrétion des lipides du lait dans la glande mammaire, Eur. J. Cell Biol. 24 (1981) 197-202.

[16] Davis D.T., Holt C., Christie W.W., The composition of milk. Biochemistry of lactation, in: Mepham T.B. (Ed.), Biochemistry of Lactation, Elsevier Science Publishers BV, 1983, pp. 71-117.

[17] Devinoy E., Stinnakre M.G., Lavialle F., Thépot D., Ollivier-Bousquet M., Intracellular routing and release of caseins and growth hormone produced into milk from transgenic mice, Exp. Cell Res. 221 (1995) 272-280.

[18] Dylewski D.P., Dapper C.H., Valivullan H.M., Deeney J.T., Keenan T.W., Morphological and biochemical characterization of possible intracellular precursors of milk lipid globules, Eur. J. Cell Biol. 35 (1984) 99-111.

[19] Fujimoto T., Kogo H., Ishiguro K., Tauchi K., Nomura R., Caveolin is targeted to lipid droplets, a new "membrane domain" in the cell, J. Cell Biol. 152 (2001) 1079-1085.

[20] Glick B., Organisation of the Golgi apparatus, Curr. Op. Cell Biol. 12 (2000) 450-456.

[21] Ghosal D., Ankrapp D., Keenan T.W., Low molecular mass GTP-binding proteins are secreted from mammary epithelial cells in association with lipids globules, Biochim. Biophys. Acta 1168 (1993) 299-306.

[22] Ghosal D., Shappell N.W., Keenan T.W., Endoplasmic reticulum lumenal proteins of rat mammary gland. Potential involvement in lipid droplet assembly during lactation, Biochim. Biophys. Acta 1200 (1994) 175-181.

[23] Heid H.W., Schnölzer M., Keenan T.W., Adipocyte differentiation-related protein is secreted into milk as a constituent of milk lipid globule membrane, Biochem. J. 320 (1996) 1025-1030.

[24] Henninghausen L., Robinson G.W., Wagner K.U., Liu W., Prolactin signaling in mammary gland development, J. Biol. Chem. 272 (1997) $7567-7569$.

[25] Houdebine L.M., The regulation of milk protein synthesis, in: Martinet J., Houdebine L.M., Head H.H. (Eds.), Biology of Lactation, INRA Editions, Chap. 16, 1999, pp. 401-427.

[26] Jensen R.G., Introduction, in: Jensen R.G. (Ed.), Handbook of milk composition, Academic Press, Chap. I, 1995, pp. 1-3.

[27] Keenan T.W., Milk lipid globules and their surrounding membrane: A brief history and perspectives for future research, J. Mam. Gland Biol. Neoplasia 6 (2001) 365-371.

[28] Keenan T.W., Patton S., The structure of milk: implications for sampling and storage, in: Jensen R.G. (Ed.), Handbook of milk composition, Academic Press, Chap. 2, 1995, pp. 5-50. 
[29] Lkhider M., Petridou B., Aubourg A., OllivierBousquet M., Prolactin signalling to milk protein secretion but not to gene expression depends on the integrity of the Golgi region, J. Cell Sci. 114 (2001) 1883-1891.

[30] Loizzi R.F., Mammary cytoskeleton and the regulation of microtubules, in: Neville M.C., Daniel C. (Eds.), The Mammary gland, Plenum Press, Chap. 5, 1987, pp. 147-179.

[31] Lollivier V., Guinard-Flament J., OllivierBousquet M., Marnet P.-G., Oxytocin and milk removal: two important sources of variation in milk production and milk quality during and between milkings, Reprod. Nutr. Dev. 42 (2002) 173-186.

[32] Lollivier V., Rainteau D., Marnet P.G., Letort S., Delpal S., Ollivier-Bousquet M., Early oxytocin effects on secretory events in rabgit and cow mammary cells, in: Baldi A., Stelwagen K. (Eds.), Fifth International Workshop on the Biology of Lactation in farm animals, Elsevier, 70, 2001, p. 180.

[33] Londos C., Brasaemle D.L., Schultz C.J., Segrest J.P., Kimmel A.R., Perilipins, ADRP, and other proteins that associate with intracellular neutral lipid droplets in animal cells, Semin Cell Dev. Biol. 10 (1999) 51-58.

[34] Martinet J., Houdebine L.M., Mammary gland, mammogenesis, growth factors, lactogenesis, in: Martinet J., Houdebine L.M., Head H.H. (Eds.), Biology of Lactation, INRA Editions, Chap. I , 1999, pp. 1-27.

[35] Mather I.H., Proteins of the milk-fat globule membrane as markers of mammary epithelial cells and apical plasma membrane, in: Neville M.C., Daniel C.W. (Eds.), The mammary gland, development, regulation and function, Plenum Press New York, 1987, pp. 217-267.

[36] Mather I.H., A review and proposed nomenclature for major proteins of the milk-fat globule membrane, J. Dairy Sci. 83 (2000) 203-247.

[37] Mather I.H., Jack L.J.W., Madara P.J., Johnson V.G., The distribution of MUC1, an apical membrane glycoprotein, in mammary epithelial cells at the resolution of the electron microscope: Implications for the mechanism of milk secretion, Cell Tissue Res. 304 (2001) 91-101.

[38] Mather I.H., Keenan T.W., Function of endomembranes and the cell surface in the secretion of organic milk constituents, in: Mephan T.B. (Ed.), Biochemistry of lactation, Elsevier Science Publishers, 1983, pp. 231-283.

[39] Mather I.H., Keenan T.W., Origin and secretion of milk lipids, J. Mam. Gland Biol. Neoplasia 3 (1998) 259-273.

[40] McManamam J.L., Hanson L., Neville M.C., Wright R.M., Lactogenic hormones regulate xanthine oxidoreductase and $\beta$-casein levels in mammary epithelial cells by distinct mechanisms, Arch. Biochem. Biophys. 373 (2000) 318-327.
[41] Monks J., Uelmen Huey P., Hanson L., Eckel R.H., Neville M.C., Gavigan S., A lipoproteincontaining particle is transferred from the serum across the mammary epithelium into the milk of lactating mice, J. Lipid Res. 42 (2001) 686-696.

[42] Murphy D.J., Vance J., Mechanism of lipidbody formation, Trends Biochem. Sci. 24 (1999) 109-115.

[43] Neveu C., Riaublanc A., Miranda G., Chich J.-F., Martin P., Is the apocrine milk secretion process observed in the goat species rooted in the perturbation of the intracellular transport mechanism induced by defective alleles at the $\alpha_{\mathrm{s} 1}-\mathrm{Cn}$ locus? Reprod. Nutr. Dev. 42 (2002) 163-172.

[44] Neville M.C., Allen J.C., Archer P.C., Casey C.E., Seacat J., Keler R.P., Lutes V., Rasbach J., Neifert M., Studies in human lactation: milk volume and nutrient composition during weaning and lactogenesis, Am. J. Clin. Nutr. 54 (1991) 81-92.

[45] Nicholas K.R., Hartmann P.E., Milk secretion in the rat: Progressive changes in milk composition during lactation and weaning and the effect of diet, Comp. Biochem. Physiol. A 98 (1991) 535-542.

[46] Nickerson S.C., Keenan T.W., Distribution and orientation of microtubules in milk secreting epithelial cells of rat mammary gland, Cell Tissue Res. 202 (1979) 303-312.

[47] Nickerson S.C., Smith J.J., Keenan T.W., Role of microtubules in milk secretion - Action of colchicine on microtubules and exocytosis of secretory vesicles in rat mammary epithelial cells, Cell Tissue Res. 207 (1980) 361-376.

[48] Ollivier-Bousquet M., Effet de l'ocytocine in vitro sur le transit intracellulaire et la sécrétion des protéines du lait, C.R. Acad. Sci. Paris 282 (1976) 1433-1436.

[49] Ollivier-Bousquet M., Early effects of prolactin on lactating rabbit mammary gland, Cell Tissue Res. 187 (1978) 25-43.

[50] Ollivier-Bousquet M., Transferrin and prolactin transcytosis in lactating mammary epithelial cell, J. Mam. Gland Biol. Neoplasia 3 (1998) 303-313.

[51] Ollivier-Bousquet M., Hormonal control of casein secretion, in: Martinet J., Houdebine L.M., Head H.H. (Eds.), Biology of Lactation, INRA Editions, Chap. 17, 1999, pp. 429-451.

[52] Ollivier-Bousquet M., Demarne Y., Effets de la prolactine sur la sécrétion des lipides du lait dans les cellules épithéliales mammaires de lapine en lactation, Reprod. Nutr. Dev. 26 (1986) 815-826.

[53] Ollivier-Bousquet M., Denamur R., Inhibition par la colchicine de la sécrétion des protéines du lait, C.R. Acad. Sci. Paris 276 (1973) 2183-2186. 
[54] Ostermeyer A.G., Paci J.M., Zeng Y., Lublin D.M., Munro S., Brown D.A., Accumulation of caveolin in the endoplasmic reticulum redirects the protein to lipid storage droplets, J. Cell Biol. 152 (2001) 1071-1078.

[55] Park D.S., Lee H., Riedel C., Hulit J., Scherer P.E., Pestell R.G., Lisanti M.P., Prolactin negatively regulates caveolin-1 gene expression in the mammary gland during lactation, via a Rasdependent mechanism, J. Biol. Chem. 276 (2001) 48389-48397.

[56] Patton S., Keenan T.W., The milk fat globule membrane, Biochim. Biophys. Acta 415 (1975) 273-309.

[57] Pauloin A., Delpal S., Chanat E., Lavialle F., Aubourg A., Ollivier-Bousquet M., Brefeldin A differently affects basal and prolactinstimulated milk protein secretion in lactating rabbit mammary epithelial cells, Eur. J. Cell Biol. 72 (1997) 324-336.

[58] Pitelka D.R., Hamamoto S.T., Ultrastructure of the mammary secretory cell, in: Mepham T.B. (Ed.), Biochemistry of Lactation, Elsevier, 1983, pp. 29-70.

[59] Pol A., Luetterforst R., Lindsay M., Heino S., Ikonnen E., Parton R.G., A caveolin dominant negative mutant associates with lipid bodies and induces intracellular cholesterol imbalance, J. Cell Biol. 152 (2000) 1057-1070.

[60] Puissant C., Bayad-Sarmadi M., Devinoy E., Houdebine L.M., Variation of transferrin mRNA concentration in the rabbit mammary gland during the pregnancy-lactation-weaning cycle and in cultured mammary cells. A comparison with the other major milk protein, Eur. J. Endocrinol. 130 (1994) 522-529.

[61] Seddiki T., Delpal S., Aubourg A., OllivierBousquet M., Endocytic prolactin routes to the secretory pathway in lactating mammary epithelial cells, Biol. Cell 94 (2002) 173-185.
[62] Seddiki T., Ollivier-Bousquet M., Temperature dependence of prolactin endocytosis and casein exocytosis in epithelial mammary cells, Eur. J. Cell Biol. 55 (1991) 60-70.

[63] Segev N., Ypt and Rab GTPases: insight into functions through novel interactions, Curr. Op. Cell Biol. 13 (2001) 500-511.

[64] Shennan D.B., Peaker M., Transport of milk constituents by the mammary gland, Physiol. Rev. 80 (2000) 925-951.

[65] Smith S.J., Cases S., Jensen D.R., Chen H.C., Sande E., Tow B., Sanan D.A., Raber J., Eckel R.H., Farese R.V., Obesity resistance and multiple mechanisms of triglyceride synthesis in mice lacking Dgat, Nat. Genet. 25 (2000) 87-90.

[66] Stemberger B.H., Patton S., Relationships of size, intracellular location, and time required for secretion of milk fat droplets, J. Dairy Sci. 64 (1981) 422-426.

[67] Valivullah H.M., Bevan D.R., Peat A., Keenan T.W., Milk lipid globules: Control of their size distribution, Proc. Natl Acad. Sci. USA 85 (1988) 8775-8779.

[68] Wolins N.E., Rubin B., Brasaemle D.L., TIP 47 associates with lipid droplets, J. Biol. Chem. 278 (2001) 5101-5108.

[69] Wooding F.B.P., The mechanism of secretion of the milk fat globule, J. Cell Sci. 9 (1971) 805-821.

[70] Wu C.C., Howell K.E., Neville M.C., Yates J.R., McManaman J.L., Proteomics reveal a link between the endoplasmic reticulum and lipid secretory mechanisms in mammary epithelial cells, Electrophoresis 21 (2000) 3470-3482.

[71] Zwierzchowski L., Hormonal control of cell division and DNA synthesis in the mammary gland, in: Martinet J., Houdebine L.M., Head H.H. (Eds.), Biology of Lactation, INRA éditions, Chap. III, 1999, pp. 57-76. 